DE DE GRUYTER

OPEN
Journal of Intercultural Management

Vol. 6, No. 2, April 2014, pp. 5-18

DOI 10.2478/joim-2014-0008

Nelly Daszkiewicz

Gdańsk University of Technology

Krzysztof Wach

Cracow University of Economics

\title{
Motives for Going International and Entry Modes of Family Firms in Poland'
}

\begin{abstract}
Currently, the internationalisation of family businesses (FBs) is an increasingly important research area. Substantial numbers of FBs are forced to expand into foreign markets in order to survive and grow in the competitive environment. However various research findings show that internationalisation of FBs may proceed differently than in the case of firms with different ownership structure. The article is both theoretical and empirical. In the theoretical part it focuses on theoretical concepts of firm internationalisation and specifics of internationalisation of FBs, especially their motives for going international. In the empirical part the quantitative approach was adopted. The results of the survey are presented on the sample of 216 firms, including 88 FBs (were investigated with the use of a survey questionnaire). Then, the statistical analysis is carried out.
\end{abstract}

Key words: family firms, internationalisation, small and medium-sized enterprises, family entrepreneurship, international entrepreneurship

\section{Introduction}

Family businesses are one of the most important sources of economic growth in a globalised world economy including wealth generation and job

1 This article came into being within the research project no. StG-21310034 entitled 'Patterns of Business Internationalization in Visegrad Countries - In Search for Regional Specifics' financed by the International Visegrad Grand IVF and conducted by five Central European universities coordinated by Krzysztof Wach from Cracow University of Economics 
creation. Contemporarily the family entrepreneurship is one of the essential dimension of the supporting and stimulating entrepreneurship in the European Union and as a very important issue for the economic policy among European countries [Wach 2013, p. 107-133]. The family firm (FF), the family business (FB), the family controlled firm (FCF) has been defined in a wide variety of ways including [Wach, Surdej 2010, pp. 11-16, 38-39; Surdej, Wach 2011, pp. 9-14, 44-45, Surdej, Wach 2012, pp. 110-112]. However, family businesses, unlike non-family businesses are influenced by family relationships that bind family members to each other and to the business. Moreover, the main value and competitive advantage of family businesses is lying in family ties that are irreplaceable [Labaki 2010, pp.41-42].

Research on family businesses has been lasting for several decades. However, the last decade brought the intensification of research on internationalisation of the firms including FBs. Hence this problem is the main theme of this research study. The objective of the paper is to identify the motives why FBs go international and to identify entry modes FBs use during their internationalisation process. The two main research methods were applied: literature review, critics and synthesis as well as the survey conducted among 216 firms. The study contains the results of empirical study that has been carried out at the turn of 2013 and 2014 on the sample of $N=216$ firm from all 16 Polish regions including $\mathrm{N}=88$ internationalised FBs.

\section{Theoretical Conceptualising the Internationalisation of the Firm}

There are many approaches to research on the internationalisation of the firm. However, there is no single theory which has received universal acceptance [Daszkiewicz, Wach, 2012, p. 70]. Initially, theories of internationalisation of the firm have been developing in the mainstream theories of international trade; the oldest of which, Adam Smith's Theory of Absolute Advantage was founded in 1776. Another group of theories developed in the mainstream of the theories of foreign direct investment (FDI).The most famous include Dunning Eclectic Theory (OLI Theory), internalization theory [Buckley, Casson 1981, pp.75-87] or transaction cost theory [Williamson, 1998; Wach 2012, pp. 9596; Daszkiewicz, Wach 2013, pp.43-44]. The development of the FDI theories was due to the increasing role of transnational corporations (TNCs) and their expansions into foreign markets in the 1970s.

The first theories of internationalisation of SMEs have been developed only in the mid-1970s. Initially they accounted for adapting the general theories of internationalisation, then their very dynamic development began and continues today.

There are several classical theories that describe internationalisation of firms as an incremental process [Johanson and Wiedersheim, 1975, Johanson 
and Vahlne 1977, Bilkey and Tesar, 1977, Cavusgil, 1980]. These so called stages theories assume that firms start their international expansion in small steps from close markets to most distant markets. Among stage theories the Uppsala Model (U-Model) is the best known and one of the most cited position [Johanson anf Vahlne, 1977, Johanson and Wiedersheim, 1975]. Some years ago Johanson and Vahlne [2009] and Schweizer, Vahlne and Johanson [2010] updated their U-model two times. The scholars emphasized the role of networks in firm internationalisation process and then the entrepreneurial approach.

However U-Model was criticized as inadequate in explaining the internationalisation of SMEs, particularly high-techs and high-tech related industries [Oviatt, McDougall, 1994]. The INV theory (International New Ventures) was based on observations that internationalisation of INV SMEs results from opportunity seeking behavior of entrepreneurs [Oviatt, McDougal, 1994, p. 49]. The INV theory states that some SMEs are "international from inception" because entrepreneurs seek growth opportunities in foreign markets. Thus, some firms can skip stages or not have any stages in all their internationalisation process. Since that time, the scholars started to differentiate two discreet ways that firms internationalize, "international at inception" [Oviatt, Mc Dougall, 1994] or "international by stage" [Johanson, Vahlne, 1977]. Wolff and Pett [2000] argued that such division represents only the end points of continuum for internationalisation. The question "might there be firms that are not international-at-founding but there are able to skip stages in their effort to internationalize? has received increased attention [Daszkiewicz, Wach, 2012, p.71].

Since Oviatt and McDougall [1994] and Wolff and Pett [2000] questioned traditional approach towards SME internationalisation, the stages theories have no longer been compulsory but still a strong paradigm of SME internationalisation process.

The last decade has been the period of rise of numerous internationalisation theories. Among them the best popular are the resource-based view [Barney, 1991], the network approach [Johanson, Mattsson, 1988, Coviello, Munro, 1999], the integrative approach [Bell at all, 2003], but also the strategic management approach as well as international entrepreneurship [Wach 2012, pp. 94-131]. The international attempt may be driven by entrepreneurs because of their individual characteristics [Zahra 2005, pp. 20-28, Busenitz, Barney 1997, p. 9-30]. A business owner, due to his/her rich industrial and international business experiences, may invest in a foreign market. In this process, the entrepreneur's personal nature plays a significant role. 


\section{Theoretical Background of the Internationalisation of Family Firms}

Various researchers have provided mixed evidence on how different factors facilitate or constrains internationalisation of FBs [Arregle, Naldi, Nordqvist, Hitt, 2012, pp. 1115]. Zahra [2003, pp. 495-512] argues that family involvement in the board of directors positively influences international sales because of the stewardship effect of family members who want to create the conditions for the firm to be long lasting for current and future generations [Zahra, 2003]. Sciascia at all [2012] found the inverted U-shaped relationship between family ownership and international intensity [Scascia, Mazzola, Astrachan, Pieper 2012, pp. 15-31].

According to Kontinen and Ojala [2010] family involvement in management may cause cautiousness in internationalisation process of family businesses. Thus, FBs are more likely to take a traditional path of internationalisation. The scholars reviewed empirical findings concerning internationalisation of FBs and founded evidence that FBs internationalisation process is gradual, consistent with internationalisation process described in Uppsala model. Moreover, FBs tend to choose psychically close countries and rather indirect than direct entry modes. In the foreign direct investment process their behavior is less formal than in case of non-FBs. What is more it might be also harder for FBs to build a portfolio of strategic resources [Kontinen, Ojala, 2010, pp. 5-6].

Arregle at all [20123] argue that the reason for these mixed results may be because the studies do not effectively account for different types of family firms which are heterogeneous. Thus, their strategic behaviors may differ, not only between family and non-family firms, but also between family firms with different attributes [Melin \& Nordqvist, 2007 quoted in: Arregle at all 2012, pp. 1115-1143]. Thus, the scholars focus on differences among family-controlled firms defined as firms in which a family unilaterally controls the firm through a majority ownership (i.e., at least $50 \%$ of the shares) and has managerial and board presence.

1. In turn, Graves and Thomas [2008, pp. 207-244] on the basis of different studies claim that FBs face unique barriers of internationalisation. However the scholar noticed that only limited number of studies have focused on factors influencing international behavior of FBs. Thus, their study explores the ways the family ownership and management influences the internationalisation of FBs. Based on the case analysis of the qualitative data, the authors defined three particular determinant of the internationalisation pathways undertaken by the eight SMFEs. These determinants (figure 1) are the degree to which the owning family was committed to internationalisation, the amount of financial resources available for internationalisation and firm's ability to develop the requisite capabilities [Graves, Thomas, 2008, pp. 155-163]: 
2. Level of commitment to internationalisation - the level of commitment towards internationalisation determines how aggressively SMFEs leveraged their resources in the international marketplace. The level of commitment of a firm to internationalisation was found to be to great extend influenced by firm's vision and objectives, whether it had opportunities to grow domestically and whether the family owners took a long-term view on financial returns (patient capital).

3. Funds available for international growth - analysis of firms showed that the internationalisation pathway was also determined by their access to financial resources and their willingness to commit financial resources into international activities eg. exhibiting at international fair trade.

4. Ability to develop the organizational capabilities required for internationalization - the ability of SMFE to grow internationally was dependent on its ability to acquire and configure its resources to develop globally relevant capabilities. These included the development of the firm's international network relationships and, particularly, their production, managerial, and marketing capabilities.

Figure 1. Determinants of the internationalisation process in family firms

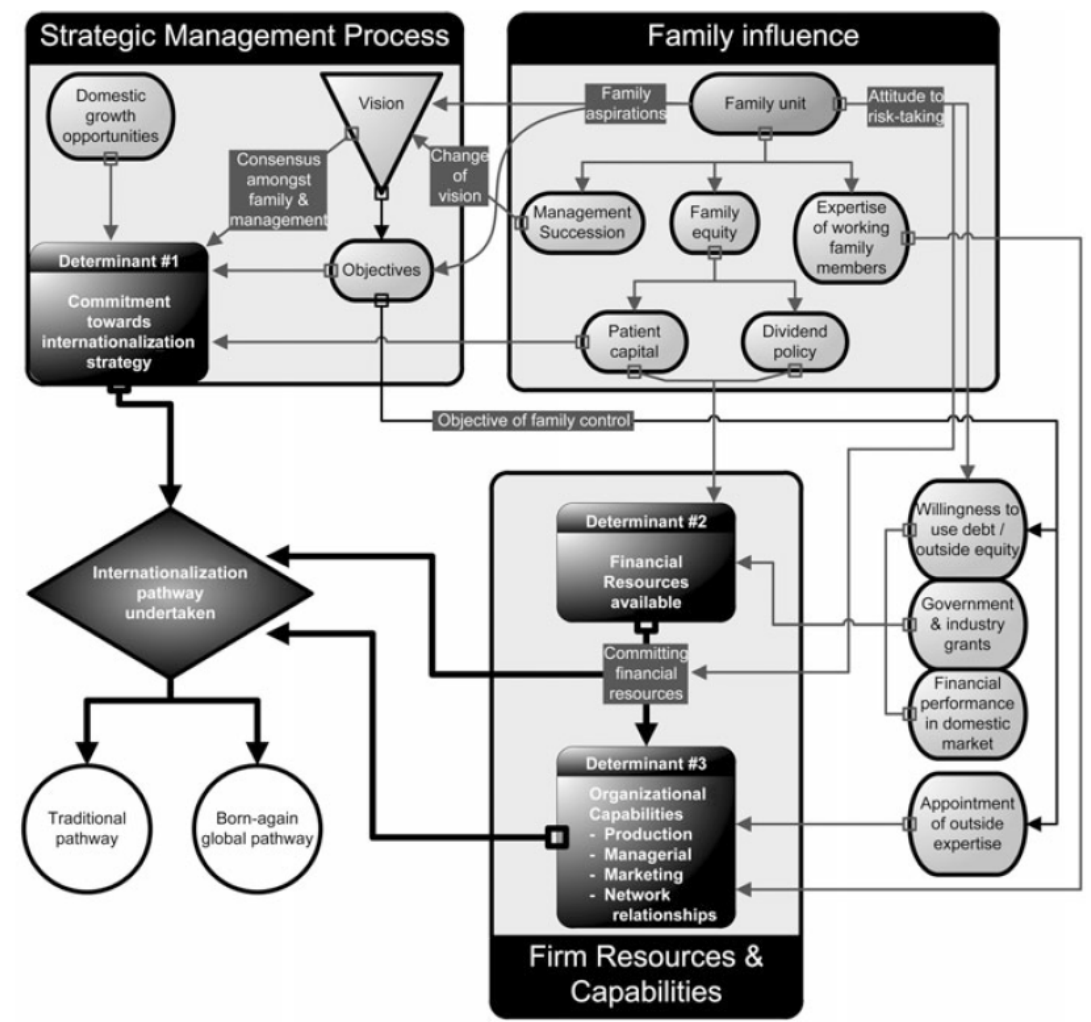

Source: [Graves, Thomas, 2008, p. 160]. 
The authors of this paper claim that internationalisation of family firm may be influenced by different factors. Some elements of the resource-based view (RBW) are adopted in this paper. Theory based on resources emphasizes the fact that SMEs are heterogenic because of the multitude of resources at their disposal and capabilities of their use. This results in an accessibility to various paths of growth, internationalisation and strategies and actions applicable for this purpose. The resource-based view argues that firms possess resources, a subset which enable them to achieve competitive advantage, and a subset of those that lead to superior long-term performance. Resources that are valuable and rare can lead to the creation of competitive advantage [Daszkiewicz, Wach 2012, p. 69-70]. However the factors unique to family firm context and its resources are the most important.

\section{Methodological Assumptions of the Empirical Research}

The research objective of the paper is to identify the motives why family firms go international as well as to identify the most popular entry modes used by family firms from the comparative perspective of family vs. non-family firms. In the course of the study, the following research hypotheses were assumed:

\begin{tabular}{|l|l|}
\hline H1: & $\begin{array}{l}\text { Family firms are mainly market seekers while going international, being much more } \\
\text { reactive on international markets. }\end{array}$ \\
\hline H2: & $\begin{array}{l}\text { Family firms extremely rare comparing to non-family firms use advanced investment } \\
\text { modes of entry into international markets. }\end{array}$ \\
\hline
\end{tabular}

The two main research methods were applied: literature review, critics and synthesis as well as the survey (an e-mail or a telephone conversation request followed by an online password protected questionnaire) conducted among 216 firms, including 88 family firms (table 1). The survey was conducted between October 2013 and February 2014 [Wach \& Wojciechowski, 2014; Daszkiewicz, 2014]. The statistical calculations were made by means of the statistical software package "Stata/SE 12.0". In order to verify the assumed hypothesis the following statistical tests were applied: Pearson's chi-square independence test as well as the logistic regression.

Table 1. Size of the family and non-family firms in the sampling

\begin{tabular}{lllllll}
\hline Size & \multicolumn{2}{l}{ Family Firms } & \multicolumn{2}{l}{ Non-Family } & Firms & All Firms \\
\hline SMEs & 79 & $90 \%$ & 85 & $66 \%$ & 164 & $76 \%$ \\
- Micro & 25 & $28 \%$ & 25 & $20 \%$ & 50 & $23 \%$ \\
- Small & 28 & $32 \%$ & 22 & $16 \%$ & 50 & $23 \%$ \\
- Medium & 26 & $30 \%$ & 38 & $30 \%$ & 64 & $30 \%$ \\
LEs & 9 & $10 \%$ & 43 & $34 \%$ & 52 & $24 \%$ \\
\hline Total & 88 & $100 \%$ & 128 & $100 \%$ & 216 & $100 \%$ \\
\hline
\end{tabular}

Source: Own study based on the research results $\left(N=216\right.$, where $\left.N_{\text {family }}=88\right)$ 


\section{Empirical Results and Discussions}

As for the internationalisation motives taxonomy according to OECD [1997a, 1997b] (fig. 2), family firms are supposed to have more active approach towards internationalisation (entrepreneurial factors and pull factors), while reactive motives are more typical for non-family firms (push factor, chance factor). However there is no statistical significance $(\mathrm{p}=0.014)$.

Figure 2. Motives for going International according to the OECD taxonomy

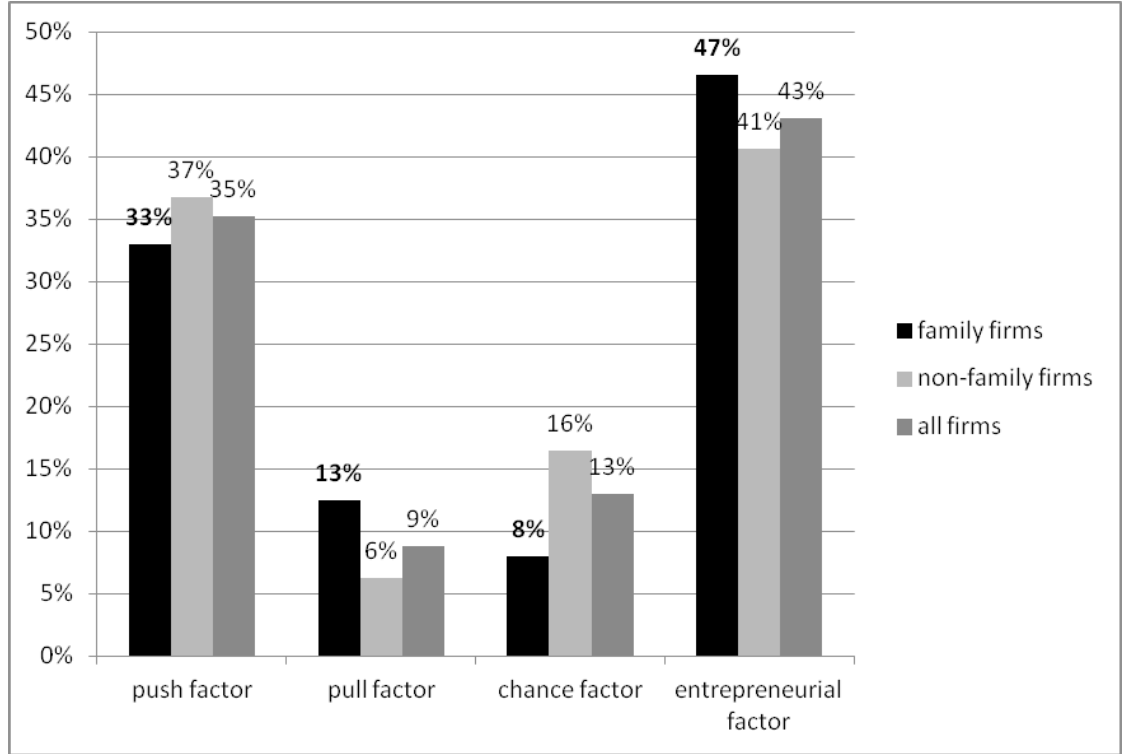

Source: Own study based on the research results $\left(N=216\right.$, where $\left.N_{\text {family }}=88\right)$.

As for Dunning's typology [Dunning, Lundan 2008, p. 67] of internationalisation motives (fig. 3), there is statistical dependence between the family firm status and the reasons for going international (chi2 $=26.3998$, $\mathrm{df}=3, \mathrm{p}=0.002)$. Family firms are mostly market seekers $(84 \%)$, while nonfamily firms apart from being market seekers (57\%), they are very often strategic assets and/or capabilities seekers (41\%).

What can be interesting, there is a relation between these two typologies of motives (table 2). All four OECD motives correspond mainly with market seeking (chi2 $=26.3998, \mathrm{df}=9, \mathrm{p}=0.002$ ). Nevertheless, if the firms go international because of being attracted by international markets, being forced to look for new markets, by chance or if they greed for dynamic growth, at the same time they are market seekers above all. 
Figure 3. Motives for going International according to Dunning's typology

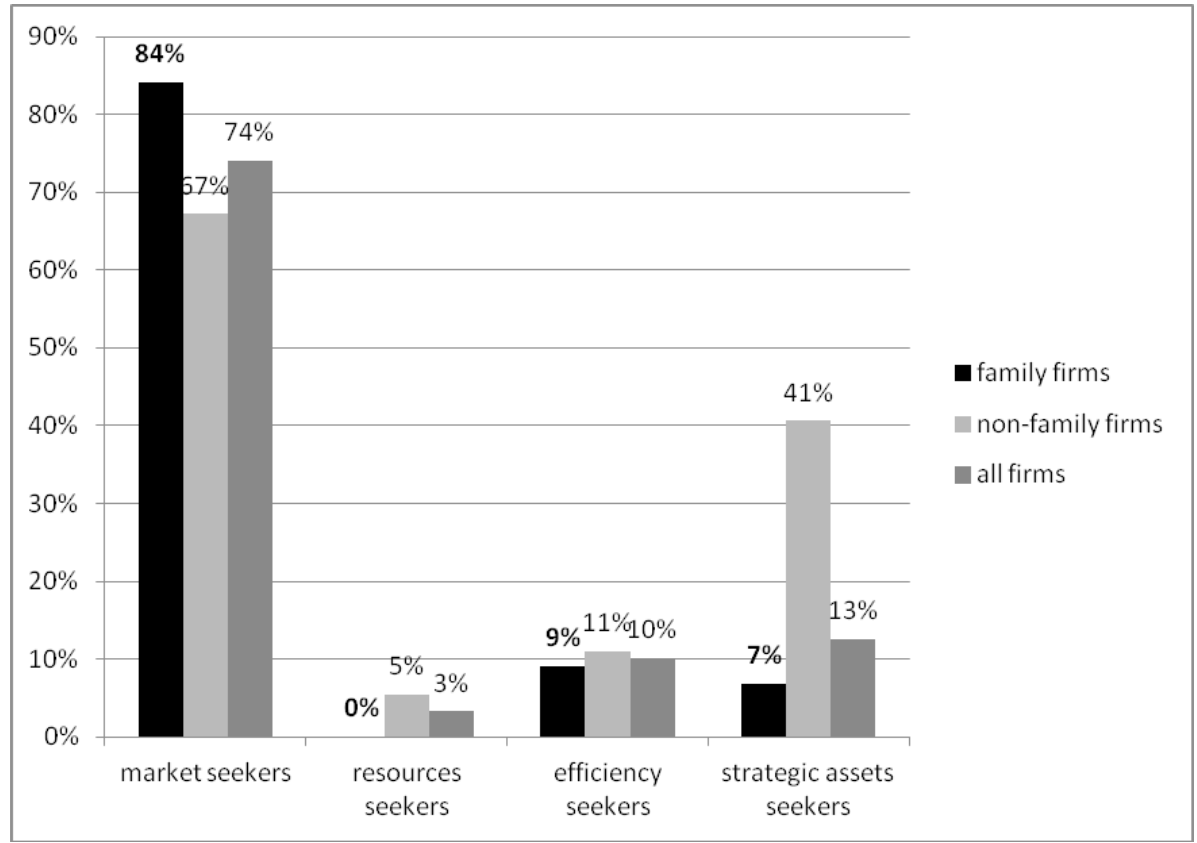

Source: Own study based on the research results $\left(N=216\right.$, where $\left.N_{\text {family }}=88\right)$.

Table 2. Cross tabulation concerning motives for going international

\begin{tabular}{llllll}
\hline Motives & $\begin{array}{l}\text { Market } \\
\text { seekers }\end{array}$ & $\begin{array}{l}\text { Resources } \\
\text { seekers }\end{array}$ & $\begin{array}{l}\text { Efficiency } \\
\text { seekers }\end{array}$ & $\begin{array}{l}\text { Strategic as- } \\
\text { sets seekers }\end{array}$ & Total \\
\hline Pull factors & 44 & 5 & 11 & 16 & 76 \\
Push factors & 13 & 0 & 2 & 4 & 19 \\
Chance factors & 24 & 1 & 3 & 0 & 28 \\
Entrepreneurial factors & 79 & 1 & 6 & 7 & 93 \\
Total & 160 & 7 & 22 & 27 & 216 \\
\hline
\end{tabular}

Source: Own study based on the research results $\left(N=216\right.$, where $\left.N_{\text {family }}=88\right)$.

The most popular entry modes [Wach 2012, p. 76-93; Daszkiewicz, Wach 2013, p. 39-45] among either family firms and non-family firms (table 3) is direct exporting (especially through a foreign distributor or own foreign representative office) as well as subcontracting. There are no statistical differences between family and non-family firms as for particular exporting (all 9 different studied modes including indirect, direct, cooperative kinds of export) and contractual modes (all 6 different studied modes). 
Table 3. Cross tabulation concerning entry modes of the studies firms

\begin{tabular}{|c|c|c|c|c|c|c|}
\hline \multirow{2}{*}{$\begin{array}{l}\text { Entry mode } \\
\text { Export commission } \\
\text { house }\end{array}$} & \multicolumn{2}{|c|}{ Family firms } & \multicolumn{2}{|c|}{ Non-family firms } & \multicolumn{2}{|c|}{ All Firms } \\
\hline & 3 & $3 \%$ & 8 & $6 \%$ & 11 & $5 \%$ \\
\hline Export/import broker & 8 & $9 \%$ & 11 & $9 \%$ & 19 & $9 \%$ \\
\hline $\begin{array}{l}\text { Export management } \\
\text { company }\end{array}$ & 3 & $3 \%$ & 3 & $2 \%$ & 6 & $3 \%$ \\
\hline Trading company & 3 & $3 \%$ & 6 & $5 \%$ & 9 & $4 \%$ \\
\hline Foreign agent & 16 & $18 \%$ & 27 & $21 \%$ & 43 & $20 \%$ \\
\hline Foreign distributor & 39 & $44 \%$ & 45 & $35 \%$ & 84 & $39 \%$ \\
\hline Representative office & 31 & $35 \%$ & 42 & $33 \%$ & 73 & $34 \%$ \\
\hline Export grouping & 7 & $8 \%$ & 8 & $6 \%$ & 15 & $7 \%$ \\
\hline Piggybacking & 3 & $3 \%$ & 10 & $8 \%$ & 13 & $6 \%$ \\
\hline Management contracts & 15 & $17 \%$ & 18 & $14 \%$ & 33 & $15 \%$ \\
\hline Assembly operations & 9 & $10 \%$ & 16 & $13 \%$ & 25 & $12 \%$ \\
\hline Subcontracting & 21 & $24 \%$ & 40 & $31 \%$ & 61 & $28 \%$ \\
\hline Turnkey operations & 3 & $3 \%$ & 8 & $6 \%$ & 11 & $5 \%$ \\
\hline Int'llicensing & 2 & $2 \%$ & 9 & $7 \%$ & 11 & $5 \%$ \\
\hline Int'l franchising & 2 & $2 \%$ & 6 & $5 \%$ & 8 & $4 \%$ \\
\hline Foreign branch & 8 & $9 \%$ & 24 & $19 \%$ & 32 & $15 \%$ \\
\hline Joint venture subsidiary & 5 & $6 \%$ & 11 & $9 \%$ & 16 & $7 \%$ \\
\hline Wholly-owned subsidiary & 8 & $9 \%$ & 21 & $16 \%$ & 29 & $13 \%$ \\
\hline
\end{tabular}

Source: Own study based on the research results $\left(N=216\right.$, where $\left.N_{\text {family }}=88\right)$.

As for investment modes, there is no difference between family and non-family firms as far as joint venture and wholly-owned subsidiaries are concerned ( $p>0.1$ ), however some slight differences can be observed from the distribution of results (wholly-owned subsidies are used almost twice as much by non-family firms). The results for a foreign branch are the only ones (out of all 18 studied entry modes) that have statistical significance (chi2 $=4.0610, \mathrm{df}$ $=1, p=0.044)$. According to the descriptive statistics $19 \%$ of non-family firms and only $9 \%$ of family firms have foreign branches.

In order to find specific features of firms having a foreign branch abroad, the logistic regression model was applied (table 3, figure 4). Being a born global reduces the likelihood of opening a branch (negative coef.), however it is difficult to explain. The share of foreign capital has a positive but insignificant effect on the probability of the opening of the branch. 
Being a family firm reduces the probability that a form will open a foreign branch (negative coef.). The business experience significantly affected the probability of opening a foreign branch (the higher level of experience, the higher probability to open a branch.

Table 3. Logistic regression for a foreign branch among studied firms

\begin{tabular}{|c|c|c|c|c|c|c|}
\hline A foreign branch | & Coef. & Std. Err. & z & $P>|z|$ & [95\% Conf. & Interval] \\
\hline Born Global & -1.057342 & .4122574 & -2.56 & 0.010 & -1.865352 & -.2493325 \\
\hline Foreign ownership & .0059818 & .0049258 & 1.21 & 0.225 & -.0036725 & .0156362 \\
\hline Family business & -.6754454 & .46447 & -1.45 & 0.146 & -1.58579 & .234899 \\
\hline Business Experience & 1.4564566 & .2352509 & 1.94 & 0.052 & -.0046268 & .9175399 \\
\hline-------- & --- & -------- & ----- & ------ & ----------- & ----------- \\
\hline$<$ constant $>$ & -2.899441 & .9259997 & -3.13 & 0.002 & -4.714367 & -1.084515 \\
\hline
\end{tabular}

Source: Own study based on the research results ( $N=216$, where $\left.N_{\text {family }}=88\right)$.

The used model was correctly classified at $85.12 \%$ (table 4 and figure 3 ), which means that the model was right in 85 out of 100 cases in assessing whether an the firm has or a foreign branch abroad or not. Therefore, one can predict with a high degree of probability whether the firm of the specific values of the indicated features (born global, foreign ownership, family business, business experience) will or will not have a chance to open a foreign branch (the area under ROC curve is 0.7145 , see fig. 3 ).

Table 4. Diagnosis of the logistic model for a foreign branch

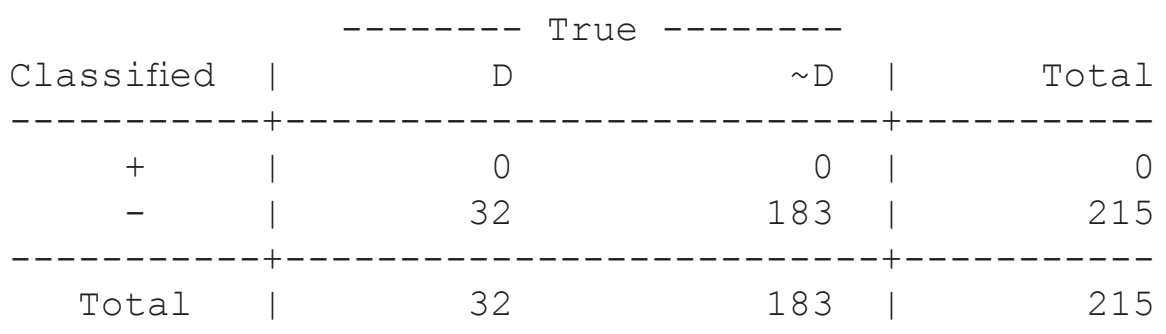

Classified + if predicted $\operatorname{Pr}(\mathrm{D})>=.5$

True $\mathrm{D}$ defined as a foreign branch $!=0$

$\begin{array}{llr}\text { Sensitivity } & \operatorname{Pr}(+\mid \mathrm{D}) & 0.00 \% \\ \text { Specificity } & \operatorname{Pr}(-\mid \sim \mathrm{D}) & 100.00 \% \\ \text { Positive predictive value } & \operatorname{Pr}(\mathrm{D} \mid+) & . \% \\ \text { Negative predictive value } & \operatorname{Pr}(\sim \mathrm{D} \mid-) & 85.12 \%\end{array}$




$\begin{array}{lllr}\text { False + rate for true } \sim \mathrm{D} & \operatorname{Pr}(+\mid \sim \mathrm{D}) & 0.00 \% \\ \text { False - rate for true D } & \operatorname{Pr}(-\mid \mathrm{D}) & 100.00 \% \\ \text { False + rate for classified + } & \operatorname{Pr}(\sim \mathrm{D} \mid+) & . \% \\ \text { False - rate for classified - } & \operatorname{Pr}(\mathrm{D} \mid-) & 14.88 \%\end{array}$

Correctly classified

$85.12 \%$

Source: Own study based on the research results $\left(N=216\right.$, where $\left.N_{\text {family }}=88\right)$

Figure 4. Diagnosis of the logistic model for a foreign branch

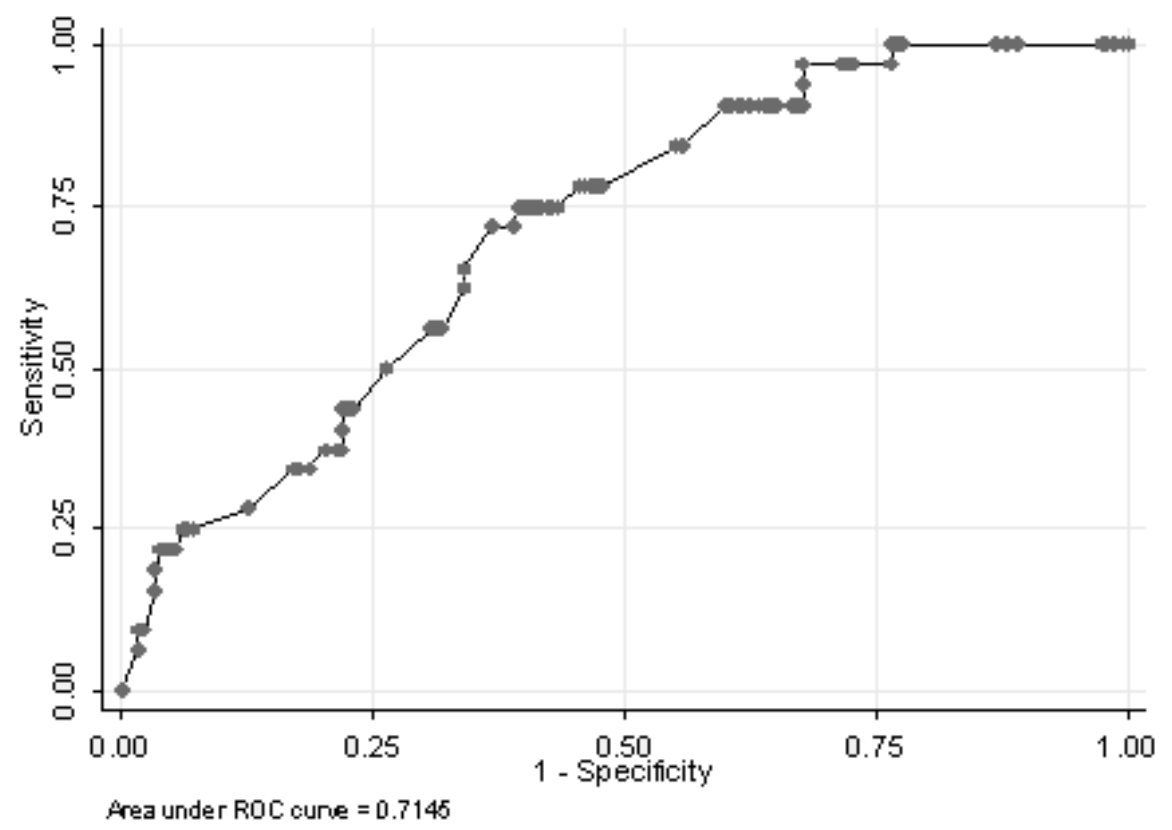

Source: Own study based on the research results ( $N=216$, where $\left.N_{\text {family }}=88\right)$.

\section{Conclusions}

Based on the calculations it was not possible to accept the given two hypotheses entirely (they have been just only partially proved), however some important trends were observed. Thus, both hypotheses were modified and the extension to 5 more detailed hypotheses were applied according to the received statistical results. The results are as follow: 


\begin{tabular}{|l|l|l|}
\hline H1: & $\begin{array}{l}\text { Family firms are mainly market seekers while going international, } \\
\text { but being much more reactive on international markets. }\end{array}$ & partially proved \\
\hline & $\begin{array}{l}\text { H1a: Family firms are mainly market seekers while going interna- } \\
\text { tional. }\end{array}$ & confirmed \\
\hline & $\begin{array}{l}\text { H1b: Family firms have much more active attitude towards inter- } \\
\text { national markets than non-family firms }\end{array}$ & confirmed \\
\hline H2: & $\begin{array}{l}\text { Family firms extremely rare compering to non-family firms use } \\
\text { advanced investment modes of entry into international markets. }\end{array}$ & partially proved \\
\hline & $\begin{array}{l}\text { H2a: Family firms much rarer than non-family firms use a foreign } \\
\text { branch as the entry mode. }\end{array}$ & confirmed \\
\hline & $\begin{array}{l}\text { H2b: Family firms much rarer than non-family firms use a foreign } \\
\text { branch as the entry mode. }\end{array}$ & $\begin{array}{l}\text { lack of signifi- } \\
\text { cance }\end{array}$ \\
\hline & $\begin{array}{l}\text { H2c: } \text { Family firms much rarer than non-family firms use a foreign } \\
\text { branch as the entry mode. }\end{array}$ & $\begin{array}{l}\text { lack of signifi- } \\
\text { cance }\end{array}$ \\
\hline
\end{tabular}

To conclude the research results, the empirical findings presented in the research paper have led to the following conclusions:

1. Family firms are supposed to have more active approach towards internationalisation (entrepreneurial factors and pull factors), while reactive motives are more typical for non-family firms (push factor, chance factor). However there is no statistical significance.

2. Family firms are mostly market seekers (84\%), while non-family firms apart from being market seekers (57\%), they are very often strategic assets and/ or capabilities seekers (41\%).

3. The most popular entry modes among either family firms and non-family firms is direct exporting (especially through a foreign distributor or own foreign representative office) as well as subcontracting . There are no statistical differences between family and non-family firms as for particular exporting.

\section{Bibliography}

Arregle J-L., Naldi L, Nordqvist M., Hitt M. (2012), Internationalization of FamilyControlled Firms: A Study of the Effects of External Involvement in Governance, "Entrepreneurship Theory \& Practice", vol. 36, no. 6, pp. 1115-1143.

Barney J.B. (1991), Firm Resources and Sustained Competitive Advantage, "Journal of Management", vol. 17., pp.99-120.

Bell J., McNaughton S., Young S., Crick D. (2003), Towards Integrative Model of Small Firm Internationalisation, "Journal of International Entrepreneurship", vol. 1, no. 4., pp.339-362.

Bilkey W.J., Tesar G. (1977), The Export Behaviour of Smaller-Sized Wisconsin Manufacturing Firms, "Journal of International Business Studies", vol. 8, no 1.

Buckley P, Casson M.C. (1981), The Optimal Timing of a Foreign Direct Investment, "Economic Journal", vol. 91, pp.75-87. 
Busenitz, L.W. and Barney, J.B. (1997), Differences between entrepreneurs and managers in large organizations: biases and heuristics in strategic decision-making, "Journal of Business Venturing" vol. 12, no. 1, pp. 9-30.

Cavusgil S.T. (1994), Differences Among Exporting Firms Based on Their Degree of Internationalization, "Journal of Business Research", vol. 12, no. 2.

Coviello, Munro, (1999), Internationalisation and the Smaller Firm: A Review of Contemporary Empirical Research, "Management International Review", vol.39, no. 3.

Daszkiewicz, N. (2014), Internacjonalizacja polskich firm rodzinnych z perspektywy przedsiebiorczosci miedzynarodowej, „Przedsiębiorczość i Zarządzanie, 2014, t. XV, z. 7, cz. 1 .

Daszkiewicz N., Wach K. (2012), Internationalization of SMEs. Context, Models, Implementation, Gdańsk University of Technology Publishers, Gdańsk 2012.

Daszkiewicz N., Wach K. (2013), Małe i średnie przedsiębiorstwa na rynkach międzynarodowych, Wyd. Uniwersytetu Ekonomicznego w Krakowie, Kraków 2013.

Dunning J.H., Lundan S.M. (2008), Multinational Enterprises and the Global Economy, 2nd edition, Edward Elgar, Chelterham - Northampton MA.

Graves C., Thomas, J. (2006), Internationalization of Australian family business: A managerial capabilities perspective, "Family Business Review", vol. 19, no. 3, pp. 207224.

Johanson J., Mattsson L.-G. (1987), Interorganizational Relations in Industrial Systems: A Network Approach Compared with the Transaction Cost Approach, "International Studies of Management \& Organization", vol. 17, no. 1.

Johanson J., Vahlne J.-E. (1977), The Internationalization Process of the Firm - A Model of Knowledge Development and Increasing Foreign Market Commitments, "Journal of International Business Studies", vol.8, no 1.

Johanson J., Vahlne J.-E. (2009), The Uppsala Internationalization Process Model Revisited: From Liability of Foreignneess to Liability of Outsidership, "Journal of International Business Studies", vol. 40, no. 9.

Johanson J., Wiedersheim P. (1975), The Internationalization of the Firm: Four Swedish Cases, "Journal of Management Studies", vol. 12, no. 3.

Kontinen T,. Ojala A. (2010), The internationalization of family businesses: A review of extant research, "Journal of Family Business Strategy", vol. 1, no. 2, pp. 97-107.

Labaki R. (201), The Financial Behaviour of Families in Business (chapter 3), In: Managing Ownership and Succession in Family Firms, eds. A. Surdej, K. Wach, Scholar, Warsaw, pp.41-42.

Melin, L. \& Nordqvist, M. (2007), The reflexive dynamics of institutionalization: The case of the family business. "Strategic Organization", vol. 5, no. 4, pp. 321-333.

OECD (1997a), Globalisation and Small and Medium Enterprises, vol. 1: Synthesis Report, Oranisation for Economic Cooperation and Development, Paris.

OECD (1997b), Globalisation and Small and Medium Enterprises, vol. 2: Country Reports, 
Oranisation for Economic Cooperation and Development, Paris.

Oviatt B.M., McDougall P.P. (1994), Toward a Theory of International New Ventures, "Journal of International Business Studies", vol. 6, no. 1.

Sciascia, S., Mazzola, P., Astrachan, J.H., Pieper, T.M. (2012), The role of family ownership in international entrepreneurship: Exploring nonlinear effects, "Small Business Economics", vol. 38, no. 1, pp. 15-31.

Surdej A., Wach K. (2010), Przedsiębiorstwa rodzinne wobec wyzwań sukcesji, Difin, Warszawa 2010.

Surdej A., Wach K. (2011), Succession Choices in Family Firms. The Case of Poland, Wydawnictwo Aadam Marszałek, Torun 2011.

Surdej A., Wach K. (2012), The Dynamics of Succession in Family Businesses in Poland Empirical Results, "Economia Marche. Journal of Applied Economics", vol. 31, no. 2, pp. 109-128.

Schweizer R., Vahlne J.-E., Johanson J. (2010), Internationalization as an Entrepreneurial Process, „Journal of International Entrepreneurship“, vol. 8, no. 4, s. 343-370.

Wach K. (2012), Europeizacja małych i średnich przedsiębiorstw: rozwój przez umiędzynarodowienie, PWN, Warszawa 2012.

Wach K. (2013), An Empirical Investigation into the EU Policy in Favour of Business Succession among Polish Family Firms, "Horyzonty Polityki" vol. 4, nr 9, s. 107-133.

Wach, K., Wojciechowski, L., The Size and the Strategic International Orientation: The Use of EPRG Model among Polish Family and Non-Family Firms, „Przedsiębiorczość i Zarządzanie, 2014, t. XV, z. 7, cz. 1, s. 143-156.

Williamson, (1998), Transaction Cost Economics. How it works?, Dec Economist, Springer. Wolff J.A., Pett T.L. (2000), Internationalization of Small Firms: An Examination of Export Competitive Patterns, Firm Size and Export Performance, “Journal of Small Business Management", vol. 38, no.2.

Zahra S.A. (2003), International expansion of U.S. manufacturing family businesses: The effect of ownership and involvement, "Journal of Business Venturing", vol. 18, no. 4, pp. 495-512.

Zahra S.A. (2005), A Theory of International New Ventures: A Decade of Research, "Journal of International Business Studies", vol. 36, no. 1, pp. 20-28. 